\title{
"Ukraine-EU cooperation for realization of innovative projects and programs aimed at public financial management modernization"
}

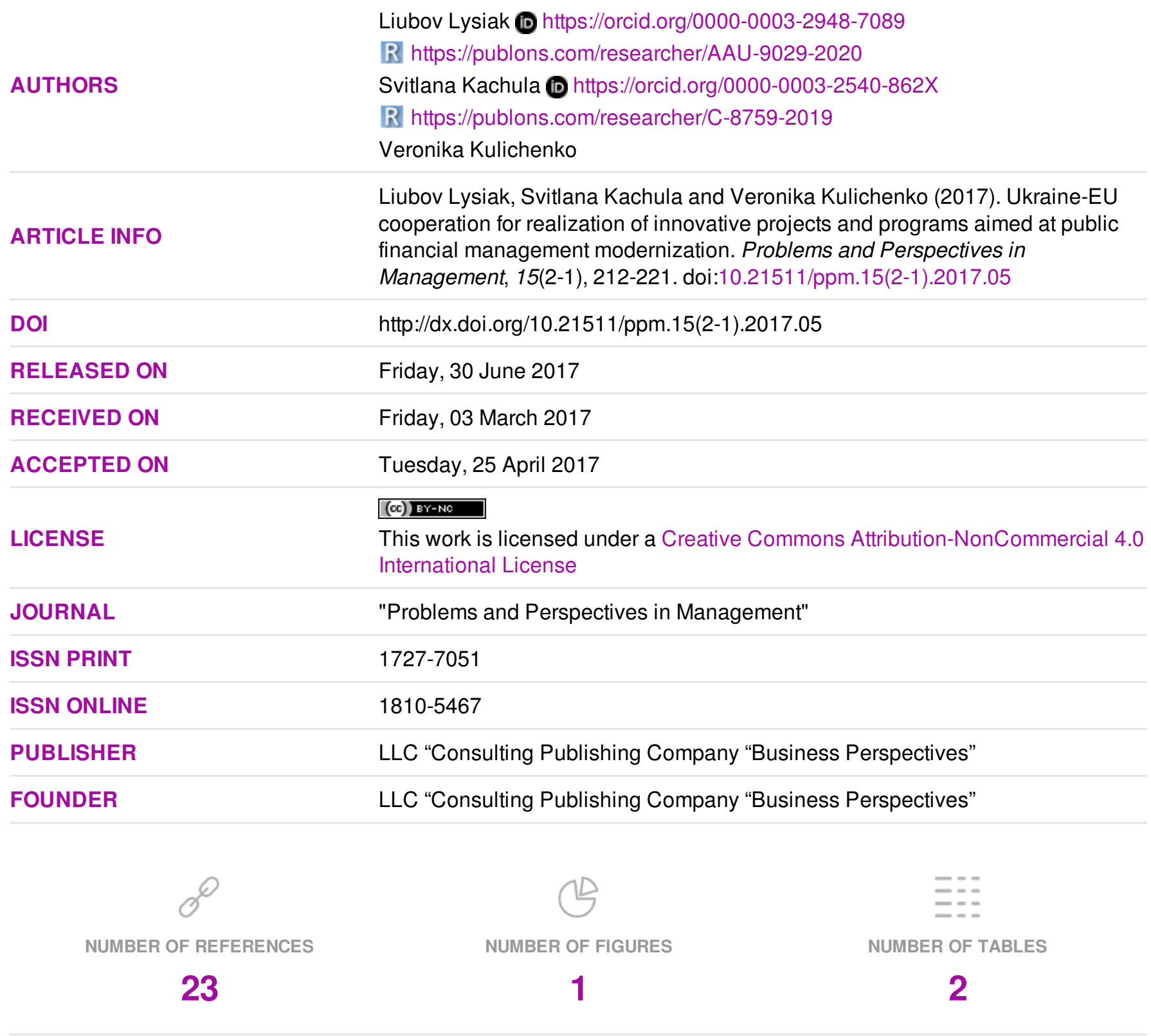

(C) The author(s) 2023. This publication is an open access article. 


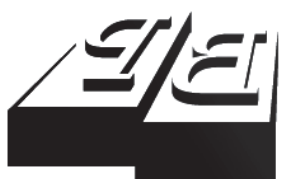

BUSINESS PERSPECTIVES

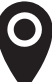

LLC “CPC "Business Perspectives” Hryhorii Skovoroda lane, 10, Sumy, 40022, Ukraine

www.businessperspectives.org

Received on: $3^{\text {th }}$ of March, 2017 Accepted on: $25^{\text {th }}$ of April, 2017

(c) Liubov Lysiak, Svitlana Kachula, Veronika Kulichenko, 2017

Liubov Lysiak, Doctor of Science (Economics), Professor, Head of Department of Finance, University of customs and finance, Ukraine.

Svitlana Kachula, Ph.D., Department of Finance, University of customs and finance, Ukraine.

Veronika Kulichenko, Assistant of the Department of Finance, University of customs and finance, Ukraine.

\section{(ㄷ)(1) (8)}

This is an Open Access article, distributed under the terms of the Creative Commons Attribution-NonCommercial 4.0 International license, which permits re-use, distribution, and reproduction, provided the materials aren't used for commercial purposes and the original work is properly cited.
Liubov Lysiak (Ukraine), Svitlana Kachula (Ukraine),

Veronika Kulichenko (Ukraine)

\section{UKRAINE-EU COOPERATION}

FOR REALIZATION OF

INNOVATIVE PROJECTS AND

PROGRAMS AIMED AT PUBLIC

FINANCIAL MANAGEMENT

MODERNIZATION

\begin{abstract}
At the present stage of economic development, Ukrainian public sector is faced with multiple new and complex challenges. In order to implement strategic reforms in the public financial management, the public authorities were given the opportunity to use external sources of finance for the implementation of relevant innovative projects and programs. Accordingly, Ukraine assumes certain international obligations towards the organizational and institutional aspects, as well as transparent and effective targeted use of financial resources. This study examined the main issues of projects and programs at each stage of the project cycle management. The main purpose of this paper is to find possibly the best basic areas for further cooperation between Ukraine and the EU on the implementation of project management in the context of the need to modernize the budget management system.
\end{abstract}

Methodological and theoretical basis of the research consists of the works of foreign and national scholars that allowed realizing conceptual integrity of the study. Methods of generalization and comparison allowed to adduce the existing projects of modernization of public financial management financed by international organizations. The authors have defined the possible forms of financing of government innovative projects and programs in Ukraine. For this purpose, methods of analysis and synthesis were used.

As a result, it is recommended to follow the directions of further cooperation between Ukraine and the EU on the development of project management along with performance-based budgeting.

\section{Keywords}

JEL Classification
Ukraine-EU cooperation, innovative projects and programs, public financial management, modernization, funding mechanisms, project management

F36, H61, O22, O19

\section{INTRODUCTION}

Ukraine's public financial management system has a number of problems and drawbacks at the present stage of development. Among them, there should be noted: inefficient public debt management system, low efficiency of the public internal financial control system, imperfect system of medium-term budget planning, orientation of budget expenditures primarily for consumption. Under conditions of increased cooperation with the European Union (hereinafter - EU), these drawbacks create barriers to economic growth due to imbalance of govern- 
ment budget, financial and material resources loss, weak possibility of creating conditions for investment and innovation. To a large extent, the listed problems are a consequence of insufficient effectiveness of forms and methods of management activities in the budget process.

Over the past ten years, the country implemented a large number of innovative projects that were financed by international organizations aimed at modernizing public financial management system, including budget management. However, implementation of these projects and programs is carried out on the basis of the functional approach and the traditional bureaucracy. It requires the search for new methods and tools for the implementation of progressive changes. In this aspect, project management is a very tangible heritage, which has emerged in the practice of the private sector, and which, as international experience shows, can be successfully used in the budget management system. Since the tools and techniques of project management contribute to achieving these goals within a specific timeframe and under the optimal use of resources on a limited budget. Therefore, strengthening of cooperation between Ukraine and the EU countries that have already achieved significant results in the implementation of project management in the field of public finance in this context is a relevant scientific and practical issue.

\section{LITERATURE REVIEW}

The fundamental points of project management theories were studied and substantiated by prominent foreign scientists, among which are: Gantt H. (1923), Kelley James E. Jr. and Walker M. R. (1989). Henry Gantt is famous for his use of the Gantt chart as a project management tool. Kelley and Walker developed the two pioneering techniques for project planning and monitoring commonly called the Critical Path Method (CPM) and Project Evaluation Review Technique.

The need and the specific direction of change in budget management in Ukraine on account of European integration, the peculiarities of project management in public administration are covered in the works of such national scientists as F. O. Yaroshenko (2010), S. D. Bushuyev (2011), V. D. Makogon (2016), T. G. Zatonatska (2011), O. A. Shymanska (2011), I. V. Edgarova (2012), V. A. Rach (2010) et al. Innovative development of the public financial system assumes first of all the use of progressive methods of budget management, the authors of the monograph "Reforming budget system of Ukraine on the innovative basis" are sure, since the level of social and economic development of individual regions and the entire state depends on the effectiveness of budget policy implementation (2010, p. 139). V. D. Makogon (2016, p. 204) rightly pointed that "the budget expenditures must be focused on creating conditions for the development and modernization of economy, efficiency of govern- ment, implementation of the strategic objectives of economic growth in the country, which will enable to increase the level and quality of life". There is no doubt about the great practical importance of analyzing the project management methods implemented in the European Union countries, USA, Canada and Russia (T. G. Zatonatska, O. A. Shymanska, 2011, p. 116). On the basis of comparative analysis of the program-target method and program-project management, they defined that application of programproject management in the sphere of public finance ensures budgetary discipline, efficient allocation of budgetary resources, the efficient use of budgetary resources at the expense of constant monitoring of project (program) indicators, helps to develop the public-private partnership.

At the same time, a study in Denmark showed that by 2020,10 billion Euros of budget funds can be saved on account of the introduction of new technologies, new knowledge and innovative processes in the state budget management system (The Danish Governments Productivity Commission, 2013). Moreover, the savings in government spending could reach $20-60 \%$ solely due to the introduction of innovative projects in the public sector (Gillison, Horne, Baeck, 2010). In addition, the EU review of the 2014 Annual Growth Survey indicates that the development of the innovative program "Electronic Government" will facilitate improvement in the efficiency of budget spending and may reduce them by $15-20 \%$ (European Commission, 2014). 
However, despite the fact that the need to use project management techniques in public financial management system was stated in those papers, specific measures for the implementation of this instrument are not well-studied.

\section{THE OBJECTIVE OF THE ARTICLE}

Given that the European Union considerably increases financial support for innovative projects and programs aimed at modernization of the public finance system, the objective of the article is to analyze the positive results and discover problems in organization of project management system in the public finance sector of Ukraine, as well as define the priority areas of cooperation between the EU and Ukraine in this context.

\section{THE CURRENT STATE OF PUBLIC FINANCIAL MANAGEMENT IN UKRAINE}

Since 2014, relations between the EU and Ukraine started to be based on qualitatively new directions, that is, economic integration and political association. The starting point of the development of these areas was signing and ratification of the Association Agreement between Ukraine and the EU. Therefore, development of the main directions of Ukraine's budget policy will further take place considering the statements of cooperation with the International Monetary Fund program and other international financial institutions.

It is well known that the global financial crisis of 2008-2009 has become the impetus for further development and reform of the public sector. In particular, many countries have implemented fiscal and tax reforms, which had a positive fiscal effect. But it should be noted that further reform of the fiscal regulation remains important, especially on the issue of fiscal decentralization and fiscal consolidation. Reforming the public finance, as well as local self-government and territorial power organization in Ukraine is continuing; the preconditions for the extension of their powers and the strengthening of financial autonomy have been made.
As international experience demonstrates, in difficult times of crisis, public sector reform becomes an essential basis for restoration of economic growth. State and local budgets are indeed strong tools in regulation of social and economic processes.

The Association Agreement with the EU again puts forward a number of demands to Ukraine for further changes in budget and tax legislation. First of all we are talking about the deepening of cooperation in management of public finance, which lies in changes of the medium-term budget planning and forecasting, perfecting the program-oriented approach to budget process and the effectiveness of implementation of budget programs, the system of internal financial control and external audit, prevention of fraud and corruption in the public sector (Bochi, 2015).

Thus, the reform of public finance management system is an essential condition for further cooperation between Ukraine and the European Commission, acting on behalf of the European Union.

A number of activities are done in Ukraine in this regard namely:

- the Sustainable Development Strategy "Ukraine - 2020" has been approved, which presupposes implementation of 62 reforms and state development programs within the vectors of development, security, responsibility and pride;

- the state regional development strategy for the period up to 2020 has been approved, which is designed in accordance with European standards, for a period synchronized with the plan and budget cycles of the EU;

- the development strategy of public finance management system and a specific plan of action for its implementation has been approved;

- the program "Reboot system of public finance of Ukraine on the basis of innovation" has been developed and implemented; 
- a draft Law of Ukraine "On State Strategic Planning" has been prepared;

- the Budget and Tax Codes are being constantly improved;

- a standard for management of innovative development based on P2M system of knowledge was introduced, which is based on the value approach in projects and programs implementation, and which is the basis of the conceptual model of innovation development of public finances;

- a system of medium-term forecasting at the national level and the level of the main managers of budgetary funds and local budgets, as well as the constant work carried out to study the possibility of full use of the mechanism of the medium-term budget forecasting has been partially introduced;

- program-target method at the level of state and local budgets has been implemented, as well as a constant improvement of the regulatory and methodological support for the preparation and implementation of state and local budgets on the basis of programtarget method is taking place;

- an advisory body of Reform Project Office (through the financial support of the EBRD) has been made, which will become a permanent project management centre.

However, under conditions when there still exists a corruption component, bureaucratic management, complications of organizational and financial procedures, such innovations result in additional barriers in the system of budget management, namely the difficulties in the work and coordination of actions of participants of the budget process. At the same time, transition to the innovative nature of the budget management system reform is an urgent requirement of modern times. Therefore, it is important at the stage of public sector reform, including public financial management, to employ new tools and methods for its implementation to ensure the goals and objectives of the reform. Project management serves as a tool that performs the necessary changes.
The modernization of the public financial management system of the EU member countries was carried out in accordance with the New Public Management model, based on applying the best management practices in the private sector to manage budget resources and relations. Therefore, every innovation, every reform that is implemented in these countries, was embodied in the form of innovative projects and programs with specific measurable goals and clearly distributed tasks, control points, and performance evaluation criteria. Taking into account the above mentioned, under conditions of transformation and globalization of the world economy, the need to improve the public finance management system in Ukraine based on the best European practices in the form of innovative projects and programs is quite obvious.

\section{EXISTING INNOVATIVE PROJECTS AND PROGRAMS IN UKRAINE}

The need for innovation in the form of projects and programs is due to the uniqueness and originality of innovation, especially in the public sector, and intensifies the lack of time and limited financial resources. Today, Ukraine has already started the process of implementing a number of innovative projects and programs aimed at improving public financial management, including budget management (Table 1).

At the same time, the experience of advanced countries shows that mainly project management, in contrast to the linear-functional one, is an integral component of effective implementation of projects and programs.

\section{FUNDING MECHANISMS OF INNOVATIVE PROJECTS AND PROGRAMS}

The choice of the funding mechanism, namely the corresponding funding systems is an equally important aspect of implementation of innovative projects and programs in the public sector. The most common ones in Ukraine are: 
Table 1. Existing innovative projects and public financial management modernization program in Ukraine

\begin{tabular}{|c|c|c|c|c|}
\hline $\begin{array}{l}\text { The name of the } \\
\text { project (program) }\end{array}$ & Total cost & $\begin{array}{l}\text { Execution } \\
\text { period }\end{array}$ & Donor & $\begin{array}{l}\text { The recipient/ } \\
\text { beneficiary }\end{array}$ \\
\hline $\begin{array}{l}\text { Decentralization Offering } \\
\text { Better Results and } \\
\text { Efficiency (DOBRE) }\end{array}$ & 50000000,00 USD & $\begin{array}{l}08.06 .2016- \\
07.06 .2021\end{array}$ & $\begin{array}{l}\text { The US Government } \\
\text { through the US Agency } \\
\text { for International } \\
\text { Development }\end{array}$ & $\begin{array}{l}\text { The Ministry of Regional } \\
\text { Development, Construction, } \\
\text { Housing and Communal } \\
\text { Services of Ukraine }\end{array}$ \\
\hline $\begin{array}{l}\text { Municipal Finance } \\
\text { Strengthening Initiative } \\
\text { (MEPI-II) implementation }\end{array}$ & 4700000 USD & $\begin{array}{l}01.10 .2011- \\
31.12 .2017\end{array}$ & $\begin{array}{l}\text { The US Government } \\
\text { through the US Agency } \\
\text { for International } \\
\text { Development }\end{array}$ & $\begin{array}{l}\text { The Ministry of Finance of } \\
\text { Ukraine }\end{array}$ \\
\hline $\begin{array}{l}\text { The development } \\
\text { of administrative } \\
\text { opportunities in the field } \\
\text { of public finance }\end{array}$ & 3000000 EUR & $\begin{array}{l}01.11 .2011- \\
31.12 .2017\end{array}$ & $\begin{array}{l}\text { The German Government } \\
\text { through the Federal } \\
\text { Ministry for Economic } \\
\text { Cooperation and } \\
\text { Development of } \\
\text { Germany (BMZ) }\end{array}$ & $\begin{array}{l}\text { The Ministry of Finance of } \\
\text { Ukraine }\end{array}$ \\
\hline $\begin{array}{l}\text { Harmonization of public } \\
\text { procurement systems in } \\
\text { Ukraine with EU standards }\end{array}$ & 3998400 EUR & $\begin{array}{l}05.11 .2013- \\
04.11 .2017\end{array}$ & European Union & $\begin{array}{l}\text { Ministry of Economic } \\
\text { Development and Trade of } \\
\text { Ukraine }\end{array}$ \\
\hline $\begin{array}{l}\text { Gender budgeting in } \\
\text { Ukraine }\end{array}$ & 46625844 SEK & $\begin{array}{l}\text { 12.11.2013- } \\
31.12 .2018\end{array}$ & $\begin{array}{l}\text { Government of } \\
\text { the Kingdom of } \\
\text { Sweden through the } \\
\text { Swedish International } \\
\text { Development Agency }\end{array}$ & $\begin{array}{l}\text { The Ministry of Finance of } \\
\text { Ukraine }\end{array}$ \\
\hline $\begin{array}{l}\text { Support to } \\
\text { decentralization in } \\
\text { Ukraine }\end{array}$ & 9277003 SEK & $\begin{array}{l}01.05 .2013- \\
30.04 .2017\end{array}$ & $\begin{array}{l}\text { Government of } \\
\text { the Kingdom of } \\
\text { Sweden through the } \\
\text { Swedish International } \\
\text { Development Agency }\end{array}$ & $\begin{array}{l}\text { The Ministry of Regional } \\
\text { Development, Construction, } \\
\text { Housing and Communal } \\
\text { Services of Ukraine }\end{array}$ \\
\hline
\end{tabular}

Source: compiled on the basis of List of international technical assistance projects (2017).

1. The state target programs implemented through budgetary programs. State target program is a set of interrelated tasks and activities aimed at solving the most essential issues of the state development, individual sectors of the economy or administrative and territorial units (Law of Ukraine, 2004). They are implemented using funds from the State Budget of Ukraine and agreed on terms of execution, the performers' composition, resource provision. Financing of innovative projects and programs at the expense of the state budget practically does not take place in Ukraine; the budget has a pronounced social orientation.

2. Loans from international financial organizations within the limits of the approved projects and programs. These loans are offered to provide a strong organizational and economic platform for the further development of private investment through the simplification of bureaucratic procedures, fighting corruption, increasing transparency of the budget process and the tax. This is evidenced by the experience of the implementation of such projects in
Central and Eastern Europe, the Middle East and Latin America (Forrester, 2011).

In Ukraine, such innovative projects and programs in the public sector are implemented with the support of the Ministry of Finance of Ukraine, research institutes and other government structures.

3. International and national grants. It is important to note that the funding of projects and programs through a grant system promotes partnerships between universities, government and the private sector.

4. International Technical Assistance (hereinafter - ITA). ITA - resources and services, in accordance with the international treaties of Ukraine, which are provided by donors on costless and irrevocable basis in order to support Ukraine (Resolution of CMU, 2002). It should be noted that in the countries of "new Europe", ITA plays a significant role in the revenue part of budget. So, in 2013, revenues from the ITA projects in Estonia local 
budgets amounted to $28 \%$ of the revenue, and in Poland $-19.5 \%$ of the national budget revenues (Analysis of the resources of international technical assistance, 2015).

5. Co-financing (co-financing of projects and programs at the expense of budget and loans from international financial institutions and/ or getting grants). One of the requirements of the majority of the international technical assistance programs is co-financing projects with the participation of local budgets.

It should be noted that with the introduction of the European Neighborhood and Partnership Instrument in Ukraine, financing of innovative projects and programs is carried out in the form of sector budget support, that is, funds provided by the European Union are an integral part of Ukraine's budget and are used in accordance with its internal procedures of public finances management (Public Finance Modernization Project, 2012).

\section{PROBLEMS OF SUCCESSFUL IMPLEMENTATION OF PUBLIC PROJECTS AND PROGRAMS IN UKRAINE}

Experience in preparation and implementation of projects, for which there were involved credits international financial organizations, shows the following. The main disadvantages of projects implementation in Ukraine are still a significant time lag of their implementation from the planned ones due to long preparation stage, as well as drawbacks in the management system and in controlling their implementation. In addition, planning and reporting on public procurement were carried out with deviations from the established processes and procedures, and the tendering with considerable delays.

Mechanisms based on the introduction of methods and project management standards, programs and portfolios of projects are already partially employed in some regions to solve the issues of low efficiency in state programs implementation, however, fragmentary use of project management tools leads to significant problems at all stages of the implementation of projects and programs.

The project cycle management methodology adopted by the European Commission in 1992 is used in the public sphere for project management (Manual Project Cycle Management, 2005). According to this methodology, project management processes form the project cycle, which consists of six stages: programming, identification, formulation, financing, implementation, evaluation and audit.

Therefore, the analysis of the issues occurring while projects and programs implementation in Ukraine will be carried out in accordance with each of the stages (Table 2).

The major problems at the planning stage are lack of national and regional strategic development guidelines, as well as lack of high-quality and clear strategic planning at the level of the main budgetary funds managers. However, it's important to take into account that the innovative projects and programs of reforming public finance system and budgetary management, in particular, did not directly address specific problems of socio-economic development of the country and its regions, but are implemented in order to optimize performance of public authorities functions and indirectly improve the efficiency of providing public services to the population, as well as improving the business climate.

Obscure mechanism of projects and programs identification stage lack formalized selection criteria that determine the ability of the political elite to lobby on their own interests for the implementation of various projects. Precise project selection mechanism is a prerequisite for effective project management, eliminates the "human factor" in determining the order of priority for private companies (Larson, Gray, 2011). Since implementation of public projects and programs aimed at improving the effectiveness of budget management under conditions of high level of corruption in Ukraine is not beneficial for many members of the political elite and requires considerable budgetary resources and costs, then, the number of interested parties here will be much higher. Arranged project selection mechanism will contribute to receiving from a wide range of stake- 
Table 2. Challenges in implementation of public projects and programs in Ukraine challenges

\begin{tabular}{|c|c|}
\hline $\begin{array}{c}\text { Project cycle } \\
\text { management stages }\end{array}$ & Challenges \\
\hline Programming & $\begin{array}{l}\text { A poor link between strategic management and implemented projects and programs, as well } \\
\text { as ensuring consistency between the priorities of Ukraine's development strategy and ITA } \\
\text { involvement programs. }\end{array}$ \\
\hline Identification & $\begin{array}{l}\text { The absence of formalized criteria for selection of projects and programs for realization, as well as } \\
\text { lack of preliminary assessment of the quality of project management, coordination and financial } \\
\text { transactions. }\end{array}$ \\
\hline Formulation & Lack of proper risk management system. \\
\hline Financing & $\begin{array}{l}\text { Underfunding and untimely budgetary funds receipt for the implementation of projects and } \\
\text { programs. Reducing the amount and extension of state target programs. Project and programs } \\
\text { selection mechanism for funding are absent. }\end{array}$ \\
\hline Introduction & $\begin{array}{l}\text { Low institutional capacity of the state machine to develop strategic programs to coordinate donors, } \\
\text { quickly register the ITA projects and programs, to provide the ITA. } \\
\text { The low level of transparency and accountability in the process of implementation of programs } \\
\text { and projects. } \\
\text { The opacity of decision-making, lack of mutual responsibility. } \\
\text { The lack of assessment of the project progress indicators. } \\
\text { The vast majority of public authorities and local governments do not have the knowledge and } \\
\text { experience in the development and project management. }\end{array}$ \\
\hline Evaluation and audit & $\begin{array}{l}\text { The absence of a mechanism for monitoring and evaluation of projects and programs. Limited } \\
\text { access to information on the status of cooperation with individual donor countries, the EU, the } \\
\text { UN and others. Lack of experience accumulation system and application of the best management } \\
\text { practice projects. The absence of projects statistical accounting system, which makes it impossible } \\
\text { to analyze the share of completed projects. }\end{array}$ \\
\hline
\end{tabular}

Source: compiled by the authors on the basis of data (Devine, 2012; Report of the Accounting Chamber of Ukraine, 2012, 2013, 2014; Sushko, 2012).

holders throughout Ukraine additional comments, observations, recommendations for projects and dialogue between them.

It is known that the project management tool was borrowed from private sector, where a successful implementation of the project depends on the efficient risks operation. Unfortunately, public sector projects proper risk management system is not available. And in that case, if risk and assumptions concerning the project are defined, the measures to minimize or neutralize them do not exist. The absence of risk management and project constraints at its formulation stage will cause further problems in complying with the timing of projects and programs.

The main problem in the next stage is projects financing issue, which is one of the key project management systems in Ukraine. Currently, selection of programs for funding is an extremely acute issue. In fact, currently no such selection is performed. The current selection mechanism is opaque, both for the main managers of funds and for the depu- ties and the public. At present, with limited funds instead of a thoroughly considered selection of programs for financing, a decrease in funding for programs after they are approved takes place. This negatively affects both the performance of the programs and the state of budget implementation.

The effective implementation of projects and programs at the national and regional levels is also constrained by a lack of awareness of heads of various levels and local communities on the use of project management principles and mechanisms. In the past few years, the situation in the sphere of specialists training in project management in Ukraine has started to change. "Project management" is entered in the list of specialties, where training specialists with higher education is conducted (8.18010013), and the national Ukrainian qualifier (Classification of Occupations) made the following professions: projects and programs managers (1238), professionals in the field of project and program management (2447), research staff (projects and programs) (2447.1), professional in project and program manage- 
ment (2447.2). Moreover, the opportunity to obtain a second higher education in the specialty "European Projects Management in 2014-2020 from Financial Perspective" has been provided.

Monitoring and evaluation of the efficiency of projects and programs implementation in Ukraine are not practically conducted. In this regard, the organizational problems encountered in projects and programs implementation are repeated from year to year. In addition, due to limited public access to information on the status of cooperation with individual states donors, the EU, the UN, the population, as the main consumers of the results of such projects and programs, are almost deprived of the opportunity to participate in the evaluation of their effectiveness.

Therefore, financial institutions put forward a number of requirements for further cooperation. In particular, the Swedish International Development Agency insists on the need to improve project management in Ukraine, especially in the context of the projects and programs implementation aimed at modernization of public financial management, despite the high degree of uncertainty and dependence of projects and reform programs on political situation (Devine, Bartholomew, Dzhygyr, 2012).

Thus, the current issues related to the improvement of project management systems and programs, has increased after Ukraine's joining to the Paris Declaration on Aid Effectiveness (presidential decree of April 19, 2007, No. 325). The following external assistance management principles are at the heart of international obligations (Sushko, 2012):

- recipient country responsibility (Ukraine should have a national development document with clear strategic priorities);

- proper public finance management (a necessity to bring the system of public procurement and public financial management in accordance with widely accepted international standards);

- alignment of aid priorities with the priorities of national development of Ukraine; managing for results (a need for development a system of projects implementing results of the analysis and their correspondence with the planned strategic directions).

\section{PRIORITY AREAS OF COOPERATION BETWEEN UKRAINE AND THE EU}

Having identified the most relevant issues in the field of project and program management, it is reasonable to identify priority areas for further cooperation between Ukraine and the EU on the development of project management in the context of the need to modernize public financial management system (Figure 1).

According to Figure 1, we consider that for the successful implementation of project management in the public financial management system, a presence of the following components is obligatory:

1) project-oriented organizational structure, which is a Project Management Office (project offices in the regions) and a Project Review Committee, as well as the integration of project management model in program-oriented model of budgetary planning. It is reasonable to do as an independent project (organizational cooperation);

2) ensuring a functional component of project management, that is, organization of all project cycle management process by forming respective competences in civil servants (social cooperation) and the availability of appropriate performance standards (methodological cooperation);

3) support of project management implementation by means of software tools (technological cooperation).

To ensure the highest efficiency of project implementation, project management introduction should take place simultaneously at national and local levels and to provide the creation of partnerships between the government, international organizations, business, civil society organizations and other stakeholders. 
Implementation of integrated information system of financial management support for project and program management processes

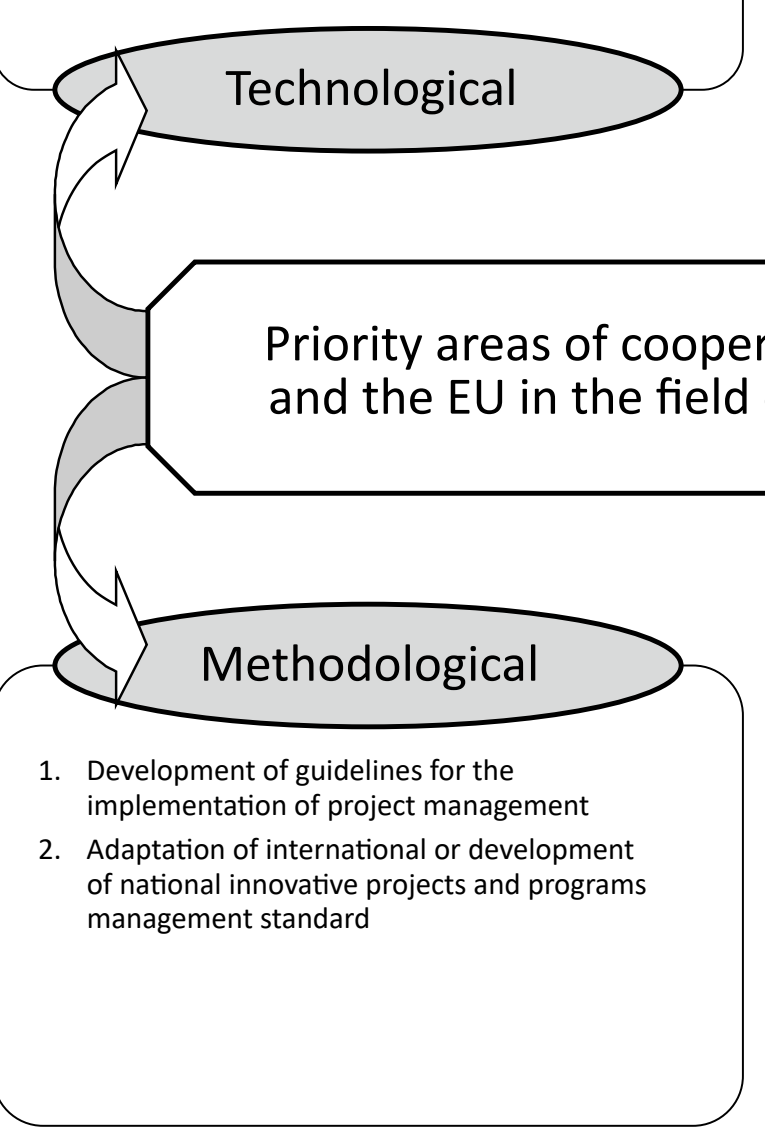

1. Projects launch the "Implementation of project management in program budgeting"

2. Establishment of project offices, as well as the Project Committee in the budget management system

3. Validating Project Management through pilot projects

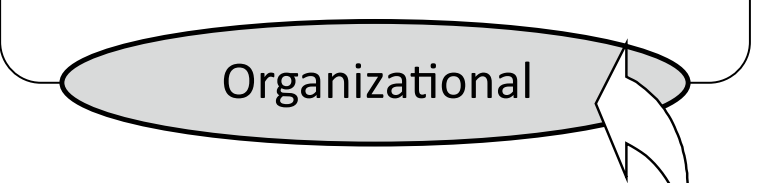

\section{ation between Ukraine f project management}




\section{REFERENCES}

1. Analiz resursiv mizhnarodnoi tekhnichnoi dopomohy, prydatnykh dlia ukrainskykh benefitsiariv (2015). Retrieved from http://dialog.lviv.ua/assets/ Analiz-resursiv.pdf

2. Bochi, A. (2015). Implementatsiia uhody pro asotsiatsiiu mizh Ukrainoiu ta YeS u torhovelnij ta biudzhetno-podatkovij sferakh. Retrieved from http://icps.com.ua/ assets/uploads/files/block_implementation_20160324.pdf

3. Clark, W. (1923). The Gantt chart, a working tool of management. Retrieved from https://archive.org/stream/ ganttchartworkin00claruoft\#page/ n7/mode/2up

4. Communication from the commission. Annual Growth Survey. (2014). Retrieved from http://ec.europa.eu/europe2020/ pdf/2014/ags2014_en.pdf

5. Devine, V., Dr V. Bartholomew, \& Y. Dzhygyr. (2012). Review of the Sida-funded Project "Advisory Support to the Ministry of Finance of Ukraine", Final Report. Retrieved from http://www.sida.se/

6. Edgarova, I. V. (2012). Suchasni pidkhodi do pobudovi modeli monitoringu progresu vikonannya poryadku dennogo asotsiatsii Ukraïna - €S: rakurs kontseptsii upravlinnya proektami. Chasopis Kiivs'kogo universitetu prava, 2, 153-155.

7. Forrester, S., Sunar, I. (2011) Developing and Managing EU-Funded Projects. Technical Assistance for Civil Society Organisations, $124 \mathrm{p}$.
8. Gillison, S. (2010). Radical efficiency - Different, better, lower cost public services. Nesta Research paper. Retrieved from http://www.nesta.org.uk/

9. Kelley James, E. Jr., Walker, M. R. (1989). The Origins of CPM: A Personal History. PMNETwork, III(2), 7-22.

10. Larson, E. W., \& Gray, C. F. (2011). Project management the managerial process. Retrieved from http://www.amazon.com/

11. Makogon, V. D. (2016). Byudzhet yak instrument ekonomichnogo zrostannya. Ekonomichniy visnik universitetu, 28(1), 203-208.

12. Manual Project Cycle Management. (2005). European Commission. Retrieved from https://ec.europa.eu/

13. Perelik diiuchykh proektiv mizhnarodnoi tekhnichnoi dopomohy, scho realizuiut'sia $\mathrm{v}$ Ukraini ta projshly derzhavnu reiestratsiiu (perereiestratsiiu) u Ministerstvi ekonomichnoho rozvytku i torhivli Ukrainy. (2017). Retrieved from https:// investcenter.km.ua/

14. Pro derzhavni tsilovi prohramy: Zakon Ukrainy nomer 1621-IV. (2004). Retrieved from http://zakon4.rada.gov.ua/

15. Pro stvorennia iedynoi systemy zaluchennia, vykorystannia ta monitorynhu mizhnarodnoi tekhnichnoi dopomohy: Poriadok nomer 153. (2002). Retrieved from http://zakon2.rada.gov.ua/
16. Proekt modernizatsii derzhavnykh finansiv: zakliuchnyj zvit. (2012). Retrieved from http://dialog.lviv.ua/

17. Rach, V. A. (2010). Upravlinnya proektami: praktichni aspekti realizatsii strategiy regionalnogo rozvitku. Kyiv: "K.I.S.".

18. Sushko, O. (2012). Uhoda pro asotsiatsiiu UkrainaYeS: dorohovkaz reform, Fond Konrada Adenatsera; Instytut Yevroatlantychnoho spivrobitnytstva.

19. The Danish Governments Productivity Commission. Analysis report. (2013). Retrieved from http://produktivitetskommissionen.dk/

20. Yaroshenko, F. O., Bushuev, S. D. (2011). Formuvannya kreativnikh modeley upravlinnya proektami rozvitku sistemi derzhavnikh finansiv Ukrainy. Finansy Ukrainy, 2, 4-10.

21. Yaroshenko, F. O. (2010). Reformuvannya byudzhetnoï sistemi Ukraïni na innovatsiynikh zasadakh, monografiya. Kiyiv: Ministerstvo finansiv Ukrainy, 544 p.

22. Zatonatska, T. G., Shimanska, O. A. (2011). Zarubizhniy dosvid zastosuvannya proektnogo menedzhmentu u sferi derzhavnogo upravlinnya. Finansi Ukrainy, 2, 106-116.

23. Zvity Rakhunkovoi palaty za 20112015 rr. (2011-2015). Rakhunkova palata Ukrainy. Retrieved from http://www.ac-rada.gov.ua/ 